\title{
Opinion Shopping, Prior Opinion, Audit Quality, Financial Condition, and Going Concern Opinion
}

\author{
Hardi HARDI ${ }^{1}$, Meilda WIGUNA ${ }^{2}$, Eka HARIYANI ${ }^{3}$, Adhitya Agri PUTRA ${ }^{4}$ \\ Received: August 01, 2020 Revised: September 20, 2020 Accepted: October 05, 2020
}

\begin{abstract}
Business going concern is an important issue to be addressed since it determines how companies will survive. One indicator of the going concern problem is going concern opinion. The going concern opinion is a result of evaluation of auditors on going concern assumption of financial reporting. This research aims to examine the effect of opinion shopping, prior opinion, audit quality, and financial condition on going concern opinion. Research sample consists of 80 listed manufacturing companies on the Indonesian Stock Exchange surveyed between 2013 and 2017. Analysis data uses logistic regression. Based on the result, prior opinion affects going concern opinion, while opinion shopping, audit quality, and financial condition have no effect on going concern opinion. The significant effect of prior opinion on going concern opinion indicates that auditors consider the evaluation of the previous condition of companies' concern problematic since going concern is hard to be solved in a short-term period. This research provides recommendations for companies to increase their business ability so going concern problem can be avoided. This research also suggests to auditors to consider prior opinion to issue current opinion since previous companies' condition can be used as a general picture to initiate the auditing process.
\end{abstract}

Keywords: Opinion Shopping, Prior Opinion, Audit Quality, Financial Condition, Going Concern Opinion

JEL Classification Code: M40, M42, G33

\section{Introduction}

Companies are founded to maintain the business going concern. Going concern is an important issue to be addressed since it determines how the business will survive. Higher performance of management brings higher possibility to ensure companies will survive. In some cases, going

${ }^{1}$ First Author. Lecturer, Department of Accounting, Faculty of Economics and Business, University of Riau, Indonesia.

Email: hardi@unri.ac.id

${ }^{2}$ Lecturer, Department of Accounting, Faculty of Economics and Business, University of Riau, Indonesia.

Email: meilda.wiguna@unri.ac.id

${ }^{3}$ Lecturer, Department of Accounting, Faculty of Economics and Business, University of Riau, Indonesia. Email: eka.hariyani@unri.ac.id ${ }^{4}$ Corresponding Author. Lecturer, Department of Accounting, Faculty of Economics and Business, University of Riau, Indonesia [Postal Address: Kampus Bina Widya KM. 12.5, Simpang Baru, Kec. Tampan, Pekanbaru, Riau, 28293, Indonesia] Email: adhitrebe@gmail.com

(C) Copyright: The Author(s)

This is an Open Access article distributed under the terms of the Creative Commons Attribution Non-Commercial License (https://creativecommons.org/licenses/by-nc/4.0/) which permits unrestricted non-commercial use, distribution, and reproduction in any medium, provided the original work is properly cited. concern problems also come from economic conditions. Economic performance can support the business to achieve a better performance. Going concern becomes a basis for assumption in financial reporting where companies assumed that they do not have any objective to reduce their business scale significantly (Astari \& Latrini, 2017). When financial reporting does not meet the going concern assumption, there is a doubt of companies' ability to maintain their business survival over a period of time, at least one year ahead since financial statement auditing date (Ikatan Akuntan Publik Indonesia, 2015b).

Business failure problem leads to going concern problem and bankruptcy risk. Indonesian Stock Exchange (IDX) keeps monitor the listed companies to ensure the prospective going concern in the future. As a result, IDX finds that Sekawan Intipratama Tbk has questionable going concern. In 2016, the company Sekawan Intipratama Tbk stopped its operational activities. Since the assessment director of IDX determined it had no business activities, thus, generating no revenues and producing continuous losses, so going concern problem occurred in Sekawan Intipratama Tbk. IDX still examines and extends the going concern criteria by involving auditor or accountant. IDX 
can suspend the stocks because of unclear going concern to reduce the investment risk. Further, IDX can force delisting of companies with suspended stocks more than two years. In some cases, IDX can give a chance for companies to keep their stock listed and allow companies to fix their performance, such as in condition where companies are in debt restructuring.

IDX also forced the delisting of company Sigmagold Inti Perkasa Tbk. The assessment director of IDX explains that IDX already gave a chance to Sigmagold Inti Perkasa Tbk to fix their financial problem more than 24 months, but the company fail to do so. The delisting process is based on two conditions. First, the company has notified significant negative impact as a business going concern, both financial and legal. Second, the company stock has been suspended from regular and money market trading for 24 months. The cases of forced delisting for going concern problem then identify impact on the financial statement for users.

One indicator of going concern problem is going concern opinion. Auditors ensure that companies have to meet the going concern assumption. When auditors perform the audit work, they also have to evaluate the doubt of business survival. If auditors have doubt about business survival, they have to issue a going concern opinion. Going concern opinion is a result of evaluation of auditors on going concern assumption of financial reporting. Going concern opinion helps external parties to evaluate companies' condition. Going concern opinion is important to give information regarding companies' status and plan for financial improvement (Menon \& Williams, 2010). It gives negative signal to shareholders. The doubt of business survival can be an indicator of early warning of bankruptcy. Going concern assumption aims to ensure that companies can run their business in a very long-term period (Astari \& Latrini, 2017). The problem of going concern can come from continuous operating losses (Krissindiastuti \& Rasmini, 2016). When auditors issue going concern opinion, there is a negative perception by the public.

Opinion shopping, prior opinion, audit quality, and financial condition can determine if companies get going concern opinion. Opinion shopping is a situation where companies' management selects the auditor who fits with the management behavior in accounting to achieve a specific financial reporting purpose. The purpose might be to get unqualified opinion from the auditor since negative audit report can give problem for companies to compete in the capital market. Opinion shopping refers to auditor switching to avoid going concern opinion. Based on opinion concept, if companies get going concern opinion, they will switch to new auditor who fit with companies' interest of non-going concern problem. When opinion shopping occurs, there is a small possibility for companies to get going concern opinion, or otherwise. Syahputra and Yahya (2017) and Kusumayanti and Widhiyani (2017) find that opinion shopping affects going concern issue, while Muslimah and Triyanto (2019) and Iriawan and Suzan (2015) do not find significant relationship between opinion shopping and going concern opinion.

Prior opinion refers to issued opinion by auditors in the previous year. Auditors also consider prior opinion to review general condition of companies, and finally, issue the current opinion (Rianto et al., 2016). Prior going concern opinion shows that companies have been in going concern problem before. It can be a guide for auditor to assess current going concern problem. Since prior going concern opinion contributes to stock price falling, limitation of capital improvement, and public trust lost; it is not easy for companies to solve going concern problem quickly (Arsianto \& Rahardjo, 2013). In this case, companies with going concern opinion in the previous period tend to get another going concern problem in the current period. Sandi et al. (2017) and Muslimah and Triyanto (2019) find that prior opinion affects current opinion, while Iriawan and Suzan (2015) do not find any significant effect of prior opinion on the current one.

DeAngelo (1981) defines audit quality as a probability where financial statement contain significant misstatement and auditors will find and report it. A high-quality audit also refers to the audit work that is consistent with auditing and quality control standards (Ikatan Akuntan Publik Indonesia, 2015c). One of audit quality indicator is Big Four affiliation. When the auditors are affiliated with Big Four auditors, they will try hard to maintain their reputation by avoiding unethical behavior. It is not easy to get non-going concern from high-quality auditor. Kristiani and Lusmeida (2018) and Difa and Suryono (2015) find that audit quality affects going concern opinion, while Effendi (2019) does not find any significant relationship between audit quality and going concern opinion.

Financial condition shows the level of financial health. Mostly going concern problem found in unhealthy companies (Ramadhany, 2004). Financial ratio can indicate the companies' financial condition. Healthy companies tend to generate higher profitability than unhealthy ones (Petronela, 2004). There is a lower probability of going concern opinion to be issued for healthy companies. Rahim (2017) and Shulhiyyah et al. (2019) find that the financial condition affects going concern opinion, while Effendi (2019) does not find any relationship between financial health and going concern opinion. This research contributes to fill the research gap, in view of inconsistent previous findings about going concern opinion, especially in emerging market such Indonesian Stock Exchange. 


\section{Literature Review}

\subsection{Agency Theory}

The agency theory explains the principal-agent contract where management act as agent to fulfill shareholders' interest (Jensen \& Meckling, 1976; Scott, 2014). Shareholders' interest as the principal is to get all information about the companies, especially about main activities where their investment fund is in there. Financial statement is one of the ways to provide companies' information on management performance for shareholders. Unfortunately, management usually engages in opportunistic behavior of financial reporting to show information about management's good performance (Hendriksen \& Breda, 1992). The agency theory assumes that agent and principal are having selfinterest, having bounded rationality, and are risk averse (Siagian, 2011).

The agent-principal conflict of interest relates to information asymmetry where financial statement information does not reflect the real condition of companies. Asymmetry information refers to the condition where one party has more information than another one (Hartono, 2015). Agents have more information about internal condition and companies' prospect than the principals do. Since financial statement provides the information of agents' performance, the agents tend to cover up their poor performance.

Auditors can mitigate the agent-principal conflict of interest. Auditors are independent parties to assess the agent performance regarding to going concern problem. For shareholders, auditors hold the role of information assurance that financial statement has been provided reasonably based on accounting standard. For management, auditors hold the role of legitimation of management performance by issuing audit opinion. Going concern opinion reflects auditors' assessment on management poor performance.

\subsection{Signaling Theory}

The signaling theory explains that information asymmetry brings companies to give signal on private information, especially information about their quality. It is important to give private information since outside investors do not have all the information that the management has. The signaling concept was formulated by Spence (1973) who examined signals in job market. Further, Ross (1977) and Battacharya (1979) developed the signaling concept into accounting and finance. Ross (1977) examined the signaling of capital structure information in the market, while Battacharya (1979) examined how market response the dividend payment.

Auditors also use the signaling concept about financial statement quality and condition of going concern. Originally, auditors have the important role to reduce information asymmetry between management and shareholders. By issuing the audit opinion, auditors give signals about private information of companies, include in going concern opinion. Going concern opinion gives information that companies have a problem of business survival and it is indicated by continuing losses and debt problem. For auditors, audit opinion captures the signal of auditor audit quality (Pham et al., 2020; Taqi, 2013), while for companies, audit opinion, as well as the change of audit opinion, captures the signal of financial statement and performance quality (Ratmono \& Nurmalasar, 2015). Taqi (2013) explains that the signal of audit quality is important for auditors to increase their reputation in the market. Ratmono and Nurmalasar (2015) also explains that qualified opinion makes companies delay the publication of financial statement because they know it gives bad news to investors.

\subsection{Hypothesis Development}

Companies engage in the opinion shopping to manipulate their financial condition. Companies switch from the old auditor who issued the going concern opinion to new auditor who accepts to issue the audit opinion the company wants. Naturally, companies want auditors to issue nongoing concern or unqualified opinions. Since going concern opinions weaken the companies' position in the capital market (Teoh \& Wong, 1993), companies have big motivation to avoid going concern opinions by doing the opinion shopping. Opinion shopping can reduce financial statement quality and credibility as well as harm the auditor's reputation. Opinion shopping shows the lack of auditor's independence. When companies are successful doing opinion shopping, a new auditor will issue the non-going concern opinion. Syahputra and Yahya (2017) and Kusumayanti and Widhiyani (2017) find that companies with opinion shopping are less likely to get going concern opinion.

\section{H1: Opinion shopping affects going concern opinion}

Audit opinion is a result of financial statement auditing process. It shows if financial statement has significant misstatement and follows the accounting standard (Ikatan Akuntan Publik Indonesia, 2015a). It also shows if companies provide the financial statement under the going concern problem. Auditors also consider prior audit opinion when issuing current audit opinion. Generally, the evaluation process of current condition always needs information about previous condition. In the context of going concern evaluation, auditors use the information of previous condition to determine the current condition of business going concern. Since it is hard to fix financial 
problem, previous problem of going concern probably continues to the current period. If companies get going concern opinion in the previous period, there is a higher probability that companies will get going concern opinion again in the current period. In contrast, if companies get non-going concern opinion in the previous period, there is a lower probability that companies will get going concern opinion again in the current period. Sandi et al. (2017) and Muslimah and Triyanto (2019) prove that auditor will issues going concern opinion for companies that get going concern opinion before.

\section{H2: Prior opinion affects going concern opinion}

The high-quality auditors have more incentives to avoid bad reputation than the low-quality ones (DeAngelo, 1981). The high-quality auditors also tend to reveal problems, include going concern problems, because they have the upper hand when faced in court. The level of audit quality is shown with the probability that auditors find companies' accounting system failure and report it as audit opinion (DeAngelo, 1981). In the context of managementshareholders relationship, there is a chance that management covers up their poor performance from shareholders. The auditors have an important role to mitigate the agency conflict and information asymmetry by revealing the bad performance of management. In this case, auditors are not only assessing the financial misstatement, but also assess the going concern problem by evaluating the management performance (Rahman et al., 2019). The auditors with high audit quality tend to issue going concern opinion especially in the context of high agency conflict condition. Kristiani and Lusmeida (2018) and Difa and Suryono (2015) find audit quality increase the probability of companies to get going concern opinion.

\section{H3: Audit quality affects going concern opinion}

Financial condition captures the financial information about current performance and future prospect (Soewiyanto, 2012). Going concern problem occurs more in unhealthy companies with poor financial performance, such as poor profitability and liquidity. For example, companies experience continuous loss and fail to build good liquidity and debt payment. Further, it leads to the higher default risk. Higher default risk indicates the going concern problems. Unhealthy companies are more likely to get going concern opinion than the healthy ones. Rahim (2017) and Shulhiyyah et al. (2019) find financial condition determine the going concern opinion.

\section{H4: Financial condition affects going concern opinion}

\section{Research Method}

\subsection{Sample}

Research sample consists of listed manufacturing companies in IDX over the 2013-2017 period. The selection of manufacturing companies aims to avoid the industrial effect of different industries subjected to the different risk of business going concern. The companies sampled also get at least one going concern opinion in the window of research period. Net sample is as in Table 1.

\subsection{Data and Variables}

Research data is made of secondary data. It is sourced from financial statements issued in IDX and Indonesian Capital Market Directory. This research uses the data to measure the research variables. Research variables consist of the dependent variable, which is going concern opinion, and independent variables, which are opinion shopping, prior opinion, audit quality, and financial condition.

Going concern is a concept of continuity of companies' business (Jones \& Belkaoui, 2009). Going concern opinion is audit opinion that explains the significant inability and uncertainty of companies' business survival in certain periods (Ikatan Akuntan Publik Indonesia, 2015b). Going concern opinion is measured by dummy variable where score 1 is for companies that get going concern opinion and score 0 otherwise. Going concern opinion includes unqualified opinion with going concern explanation, unqualified opinion with exception, qualified opinion, and disclaimer opinion.

Opinion shopping refers to companies switching auditor to get non-going concern opinion (Kusumayanti \& Widhiyani, 2017). Opinion shopping is measured by dummy variable: score 1 if companies do the opinion shopping and score 0 otherwise. Prior opinion is audit opinion issued by auditor in the previous period (Syahputra \& Yahya, 2017). Prior opinion is measured by dummy variable: score 1 if companies get going concern opinion and score 0 otherwise. Audit quality is the ability of auditors to find significant misstatement and report it into audit opinion. Audit quality is measured by dummy variable: score 1 if auditor has Big Four affiliation and score 0 otherwise (DeAngelo, 1981). Financial condition refers to the financial risk where high financial risk is indicator of unhealthy financial condition (Kakinuma, 2020; Soewiyanto, 2012). Financial risk is measured by debt-to-equity ratio, while unhealthy financial condition is measured by dummy variable: score 1 if debt-to-equity ratio is above 1 or below 0 and score 0 if debt-to-equity ratio is below 1 (Shulhiyyah et al., 2019). 
Table 1: Sample

\begin{tabular}{|l|c|c|}
\hline Criteria & Companies & $\begin{array}{c}\text { Companies- } \\
\text { Years }\end{array}$ \\
\hline $\begin{array}{l}\text { Listed manufacturing } \\
\text { companies in IDX period } \\
2012-2017\end{array}$ & 164 & 820 \\
\hline $\begin{array}{l}\text { Does not get going concern } \\
\text { opinion in 2012-2017 }\end{array}$ & $(148)$ & $(740)$ \\
\hline Net Sample & 16 & 80 \\
\hline
\end{tabular}

\subsection{Data Analysis}

The analysis uses logistic regression. Logistic regression examines the probability of specific category since the dependent variable is a categorical variable (Ghozali, 2011). Logistic regression analysis includes overall model fit test, goodness of fit test, coefficient of determinant test, classification matrix, and hypothesis test. Regression model is formulated as in equation (1).

$$
\begin{aligned}
\operatorname{Ln}(G C O /(1-G C O))= & a+b 1 O S+b 2 P O+b 3 A Q \\
& +b 4 F I N+e
\end{aligned}
$$

Where $G C O$ is going concern opinion, $O S$ is opinion shopping, $P O$ is prior opinion, $A Q$ is audit quality, and FIN is financial condition. $\mathrm{H} 1$ is accepted if $\mathrm{b} 1$ is negative and significant, $\mathrm{H} 2$ is accepted if $\mathrm{b} 2$ is positive and significant, $\mathrm{H} 3$ is accepted if b3 is positive and significant, and H4 is accepted if $b 4$ is positive and significant.

\section{Results and Discussion}

\subsection{Descriptive Statistics}

Research Table 2 shows 45 samples or $56.2 \%$ of total 80 samples get going concern opinion while 35 samples or $43.8 \%$ of total 80 samples get non-going concern opinion. Opinion shopping is measured by nine samples or $11.2 \%$ of total 80 samples, while 71 samples or $88.8 \%$ of total 80 samples do not do opinion shopping. There are 43 samples or $53.8 \%$ of total 80 samples that get going concern opinion in the previous period, while 37 samples or $46.2 \%$ of total 80 samples get non-going concern opinion in the previous year. High audit quality is performed in 15 samples or $18.8 \%$ of total 80 samples, while low audit quality is performed in 65 samples or $81.2 \%$ of total samples. There are 65 samples or $81.2 \%$ of total samples that experience the unhealthy financial condition, while there are 15 samples or $18.8 \%$ of total 80 samples that experience the healthy financial condition.
Table 2: Descriptive Statistics

\begin{tabular}{|l|c|c|}
\hline \multirow{2}{*}{ Variable } & \multicolumn{2}{|c|}{ Sample } \\
\cline { 2 - 3 } & Yes & No \\
\hline $\begin{array}{l}\text { Going Concern } \\
\text { Opinion }\end{array}$ & $\begin{array}{c}45 \\
(56.2 \% \text { of total })\end{array}$ & $\begin{array}{c}35 \\
(43.8 \% \text { of total })\end{array}$ \\
\hline Opinion Shopping & 9 & 71 \\
$(11.2 \%$ of total $)$ & $(88.8 \%$ of total $)$ \\
\hline $\begin{array}{l}\text { Prior Going Concern } \\
\text { Opinion }\end{array}$ & $\begin{array}{c}43 \\
(53.8 \% \text { of total })\end{array}$ & $\begin{array}{c}37 \\
(46.2 \% \text { of total })\end{array}$ \\
\hline High Quality Auditor & 15 & 65 \\
$(18.8 \%$ of total $)$ & $(81.2 \%$ of total $)$ \\
\hline $\begin{array}{l}\text { Unhealthy Financial } \\
\text { Condition }\end{array}$ & $\begin{array}{c}65 \\
(81.2 \% \text { of total })\end{array}$ & $\begin{array}{c}15 \% \text { of total }) \\
(18.8 \%\end{array}$ \\
\hline
\end{tabular}

Table 3: Overall Model Fit Test

\begin{tabular}{|l|c|}
\hline Step & $\begin{array}{c}\text { Value of -2Log- } \\
\text { Likelihood }\end{array}$ \\
\hline $\begin{array}{l}\text { Step 0: Before involves the } \\
\text { independent variables }\end{array}$ & 109.650 \\
\hline $\begin{array}{l}\text { Step 1: After involves the } \\
\text { independent variables }\end{array}$ & 63.837 \\
\hline Differences & $45.814^{*}$ \\
\hline
\end{tabular}

Note: * indicates significant at $1 \%$ level of significance based on chi-square statistics.

Table 4: Hosmer and Lemeshow's Test

\begin{tabular}{|l|c|}
\hline Chi-Square & Significance \\
\hline 4.669 & 0.587 \\
\hline
\end{tabular}

\subsection{Overall Model Fit}

Overall model fit aims to assess the fitness of the model with the data. It examines the likelihood model before and after involving the independent variables. Overall model fit test result shown in Table 3. The value of $-2 \log$-likelihood before involving the independent variables is 109.650. Value of -2log-likelihood after involving the independent variables is 63.837. The difference value is 45.814 (significant in 0.01 ). Reduction value of $-2 \log$-likelihood shows that the model is better when the independent variables are involved and it fits with the data.

\subsection{Goodness of Fit Test}

Goodness of fit test aims to examine if the model can predict its observed value. Goodness of fit test uses Hosmer and Lemeshow's test. The result is shown in Table 4. Chisquare value is 4.669 with significance value of 0.587 (insignificant). The result indicates that the model fits with the observed value and can predict its observed value. 


\subsection{Coefficient of Determinant}

Coefficient of determinant shows the explanatory power of independent variables to predict the probability of going concern opinion. It uses the value of Nagelkerke R-square between $0 \%$ until $100 \%$. Based on proceed data, the value of Nagelkerke R-square is 0.584 . It indicates that opinion shopping, prior opinion, audit quality, and financial condition can explain $58.4 \%$ of going concern opinion, while $41.6 \%$ of going concern opinion is explained by other variables outside the research model.

\subsection{Classification Matrix}

Classification matrix shows the prediction power of the regression model to predict going concern opinion. The result is shown in Table 5. Based on 35 non-going concern opinions, the model can predict correctly 29 nongoing concern opinions with percentage correct of $82.9 \%$. Based on 45 going concern opinions, the model can predict correctly 39 going concern opinions with percentage correct of $86.7 \%$. Overall percentage correct of the model is $85.0 \%$ can predict the probability of audit opinion.

\subsection{Hypothesis Testing and Discussion}

Table 6 shows that opinion shopping has a coefficient value of 1.868 with Wald-statistics of 2.002 (insignificant). It indicates that $\mathrm{H} 1$ is rejected. Opinion shopping does not affect going concern opinion. Opinion shopping occurs when companies switch their auditor because in the previous period they get going concern opinion. Not all auditor switching comes with a result of non-going concern opinion for the current period. In the context of opinion shopping, auditor switching also considers some factors such as the change of audit opinion from going concern to non-going concern opinion, change of audit quality from high to lowquality, change of financial statement quality from high to low-quality, and effectiveness of regulator's role. Lack of these factors prevents this research from finding a significant effect of opinion shopping on going concern opinion. Since auditor switching still generates going concern opinion, high-quality audit, high-quality financial statement, and effective monitoring role from regulator; opinion shopping does not occur. This result is not consistent with Syahputra and Yahya (2017) and Kusumayanti and Widhiyani (2017) who find that opinion shopping affects going concern issue.

Prior opinion has coefficient value of 2.400 with Waldstatistics of 25.742 (significant in 0.01). It indicates that $\mathrm{H} 2$ is accepted. Prior opinion affects going concern opinion. Current auditing process always considers previous auditing result as a guidance to find audit evidence, including in considering prior audit opinion. When companies get going concern opinion in the previous period, the auditor has an initial clue that companies have poor performance and financial problem. In this case, it is easier for the auditor to evaluate and find the evidence of going concern problem. Since the consequences of going concern problems are hard to be fixed, there is high probability that companies will get going concern opinion again in the current period. This result is consistent with Sandi et al. (2017) and Muslimah and Triyanto (2019) who find that prior opinion affects current opinion.

Audit quality has coefficient value of 0.314 with Waldstatistics of 0.138 (insignificant). It indicates that $\mathrm{H} 3$ is rejected. Audit quality does not affect going concern opinion. Audit quality occurs when auditors give going concern opinion for unhealthy companies and give nongoing concern opinion for healthy ones. The high-quality auditors do not always issue going concern opinion since it depends on companies' condition. The high-quality auditors tend to give going concern opinion in the context of higher agency conflict and information asymmetry. Generally, audit quality refers more to the audit opinion accuracy than the type of opinion. This research is not consistent with Kristiani and Lusmeida (2018) and Difa and Suryono (2015) who find audit quality increase the probability of companies to get going concern opinion.

Table 5: Classification Matrix

\begin{tabular}{|l|c|c|c|}
\hline \multirow{2}{*}{ Observed } & \multicolumn{2}{|c|}{ Predicted } & \multirow{2}{*}{ Correct } \\
\cline { 2 - 3 } & $\begin{array}{c}\text { Non-Going } \\
\text { Concern } \\
\text { Opinion }\end{array}$ & $\begin{array}{c}\text { Going } \\
\text { Concern } \\
\text { Opinion }\end{array}$ & \\
\hline $\begin{array}{l}\text { Non-Going } \\
\text { Concern Opinion }\end{array}$ & 29 & 6 & $82.9 \%$ \\
\hline $\begin{array}{l}\text { Going Concern } \\
\text { Opinion }\end{array}$ & 6 & 39 & $86.7 \%$ \\
\hline Overall & \multicolumn{2}{|c|}{} \\
\hline
\end{tabular}

Table 6: Hypotheses Test

\begin{tabular}{|l|c|c|}
\hline Variable & Coefficient & Wald \\
\hline Opinion Shopping & 1.868 & 2.002 \\
\hline Prior Opinion & 2.400 & $25.742^{*}$ \\
\hline Audit Quality & 0.314 & 0.138 \\
\hline Financial Condition & 0.500 & 0.327 \\
\hline Constant & -2.037 & \\
\hline
\end{tabular}

Note: * indicates significant at $1 \%$ level of significance based on z-statistics. 
Financial condition has coefficient value of 0.500 with Wald-statistics of 0.327 (insignificant). It indicates that H4 is rejected. Financial condition does not affect going concern opinion. This research measures financial condition from debt default. There is a possibility that going concern evaluation by auditors does not use debt default only. Going concern opinion comes from both debt default and profitability (Soewiyanto, 2012). If companies have higher risk of debt, at the same time, have high profitability $(\mathrm{Vu}$ et al., 2019), then companies can reduce the risk further, and going concern opinion will not be given. There is wider spectrum of financial condition to determine that companies are in going concern problem. For example, losses indicator, debt payment failure, suspended stock in the stock market, and legal issue. This result is not consistent with Rahim (2017) and Shulhiyyah et al. (2019) who find financial condition determine the going concern opinion.

\section{Conclusion}

This research objective is to examine the effect of opinion shopping, prior opinion, audit quality, and financial condition on going concern opinion. Based on analysis, prior opinion affects going concern opinion. Generally, auditor will use previous evaluation as initial guidance to do auditing and issue the audit opinion. Since going concern problem is not easy to be fixed, there is a high probability that companies with going concern opinion can still get the same opinion in the future. On the other hand, there is no effect of opinion shopping, audit quality and financial condition on going concern opinion.

This research implies that companies should increase their business ability so going concern problem can be avoided. This research also implies that auditors should consider prior opinion to issue current opinion since previous companies' condition is effective to be used as a general picture to initiate auditing process. Future research should consider financial statement quality, regulator role, and comprehensive financial condition to determine the going concern opinion since this research does not find that opinion shopping, audit quality, and financial condition affect going concern opinion because of the lack of those factors.

\section{References}

Arsianto, M. R., \& Rahardjo, S. N. (2013). Faktor-Faktor yang Mempengaruhi Penerimaan Opini Audit Going Concern. Diponegoro Journal of Accounting, 2(3), 572-579.

Astari, P. W., \& Latrini, M. Y. (2017). Faktor- Faktor yang Mempengaruhi Penerimaan Opini Audit Going Concern. E-Journal Akuntansi Universitas Udayana, 19(3), 2407-2438.

Battacharya, S. (1979). An Exploration of Nondissipative DividendSignaling Structures. Journal of Financial and Quantitative Analysis, 14, 667-668.
DeAngelo, L. E. (1981). Auditor Size and Audit Quality. Journal of Accounting and Economics, 3(3), 183-199. https://doi. org/10.1016/0165-4101(81)90002-1

Difa, R. A., \& Suryono, B. (2015). The Influence of Finance, Auditor Quality, Company Ownership on Acceptance of Going Concern Audit Opinions. Jurnal Ilmu \& Riset Akuntansi, 4(8), 1-20. [Indonesian]

Effendi, B. (2019). Audit Quality, Financial Condition, Company Size and Acceptance of Going Concern Audit Opinions. Owner: Riset \& Jurnal Akuntansi, 3(1), 9-15. https://doi.org/10.33395/ owner.v3i1.80 [Indonesian]

Ghozali, I. (2011). Multivariate Analysis with the Program IBM SPSS 19 (5th ed.). Jakarta, Indonesia: BPFE UNDIP. [Indonesian]

Hartono, J. (2015). Theory of Portfolio and Investment Analysis (10th ed.). Jakarta, Indonesia: BPFE UGM.

Hendriksen, E. S., \& Breda, M. F. Van. (1992). Accounting Theory (5th ed.). Toronto, Canada: Irwin.

Ikatan Akuntan Publik Indonesia. (2015a). Overall Objective of the Independent Auditor and the Conduct of Audit in Accordance with Standards on Auditing. Jakarta, Indonesia: IAPI.

Ikatan Akuntan Publik Indonesia. (2015b). Going Concern. Jakarta, Indonesia: IAPI.

Ikatan Akuntan Publik Indonesia. (2015c). Audit Standards Section 150: Auditing Standards. Jakarta, Indonesia: IAPI. [Indonesian]

Iriawan, W. P., \& Suzan, L. (2015). The Influence of Company Growth, Opinion Shopping, and Prior Opinion on Acceptance of Going Concern Audit Opinions (Studies on Property and Real Estate Companies Listing on the IDX in 2009-2013. E-Proceeding of Management, 2(2), 1683-1690. [Indonesian]

Jensen, M. C., \& Meckling, W. H. (1976). Theory of the firm: Managerial behavior, agency costs and ownership structure. Journal of Financial Economics, 3(4), 305-360. https://doi. org/10.1016/0304-405X(76)90026-X

Jones, S., \& Belkaoui, A. R. (2009). Financial Accounting Theory (3rd ed.). Cengage Learning Australia.

Kakinuma, Y. (2020). Return Premium of Financial Distress and Negative Book Value: Emerging Market Case. Journal of Asian Finance, Economics and Business, 7(8), 25-31. https://doi. org/10.13106/jafeb.2020.vol7.no8.025

Krissindiastuti, M., \& Rasmini, N. K. (2016). Factors Affecting Going Concern Audit Opinions. E-Journal Akuntansi Universitas Udayana, 14(1), 451-481. [Indonesian]

Kristiani, M., \& Lusmeida, H. (2018). The Effect of Company Growth, Liquidity and Audit Quality on Going Concern Audit Opinions: Empirical Studies on the Property and Real Estate Industry in the Indonesia Stock Exchange. Seminar Nasional Dan Call for Paper: Manajemen, Akuntansi Dan Perbankan, 649-663. [Indonesian]

Kusumayanti, N. P. E., \& Widhiyani, N. L. S. (2017). Effect of Opinion Shopping, Disclosure and Reputation of KAP on Going Concern Audit Opinions. E-Jurnal Akuntansi Universitas Udayana, 18(3), 2290-2317. [Indonesian] 
Menon, K., \& Williams, D. D. (2010). Investor Reaction to Going Concern Audit Reports. The Accounting Review, 85(6), 20752105. https://doi.org/10.2308/accr.2010.85.6.2075

Muslimah, O., \& Triyanto, D. N. (2019). The Influence of Company Growth, Prior Opinion, Debt Default and Opinion Shopping on the Acceptance of Going Concern Audit Opinions (Studies on Mining Sector Companies Listed on the Indonesia Stock Exchange in 2013-2017). Jurnal Akuntansi, Audit Dan Sistem Informasi Akuntansi, 3(2), 229-242. [Indonesian]

Petronela, T. A. (2004). Going Concern Considerations for the Company in Providing an Audit Opinion. Jurnal Akuntansi, Auditing Dan Keuangan, 1(1), 46v55. [Indonesian]

Pham, C. B. T., Vu, T. M. T., Nguyen, L. H., \& Nguyen, D. D. (2020). Audit Quality and Stock Return Co-Movement: Evidence from Vietnam. Journal of Asian Finance, Economics and Business, 7(7), 139-147. https://doi.org/10.13106/jafeb.2020.vol7.no7.139

Rahim, S. (2017). The Influence of Company Financial Conditions, Audit Quality and Opinion Shopping on Acceptance of Going Concern Opinions. Jurnal Ilmiah Akuntansi Dan Bisnis, 11(2), 75-83. https://doi.org/10.24843/JIAB.2016.v11.i02.p02

Rahman, M. M., Meah, M. R., \& Chaudhory, N. U. (2019). The Impact of Audit Characteristics on Firm Performance: An Empirical Study from an Emerging Economy. Journal of Asian Finance, Economics and Business, 6(1), 59-69. https://doi. org/10.13106/jafeb.2019.vol6.no1.59

Ramadhany, A. (2004). Analysis of Factors Affecting Acceptance of Going Concern Opinions in Manufacturing Companies Experiencing Financial Distress on the Jakarta Stock Exchange. Jurnal MAKSI, 4(August), 146-160. [Indonesian]

Ratmono, D., \& Nurmalasar, D. (2015). Is an Audit Opinion a Good News? Testing Signaling Theory. Jurnal Akuntansi Indonesia, 4(1), 1-11. [Indonesian]

Rianto, K., Hasan, A., \& A. Al Azhar. (2016). The Effect of Auditor Quality, Debt Default, Opinion Shopping, Previous Year's Audit Opinion and Kap Reputation on the Acceptance of Going Concern Audit Opinions (Empirical Studies on Manufacturing Companies in Bei). JOM FEKON, 3(1), 264-278. [Indonesian]

Ross, S. A. (1977). The Determination of Financial Structure: The Incentive Signaling Structure. Bell Journal of Economics, 8, 23-40.
Sandi, L. D., Prasetyo, A., \& Kurniawati, E. T. (2017). Effect of Debt Default, Firm Size, and Prior Opinion on Acceptance of Going Concern Opinions. Jurnal Reviu Akuntansi Dan Keuangan, 4(1), 571-578. https://doi.org/10.22219/jrak. v4i1.4930 [Indonesian]

Scott, W. R. (2014). Financial Accounting Theory (7th ed.). Englewood Cliffs, NJ: Prentice Hall.

Shulhiyyah, F., Afifudin, A., \& Mawardi, M. C. (2019). The Influence of Financial Conditions, Auditor Reputation, Audit Tenure, and Previous Year's Audit Opinion on Going Concern Audit Opinion Disclosures (Studies of Manufacturing Companies Listed on the IDX 2015-2017). Jurnal Ilmiah Riset Akuntansi, 8(3), 29-43. [Indonesian]

Siagian, S. P. (2011). Human Resource Management. Jakarta, Indonesia: Bumi Aksara.

Soewiyanto, A. M. (2012). Aspects of Giving Going Concern Audit Opinions. Jurnal Ilmiah Mahasiswa Akuntansi, 1(2), 106-110. [Indonesian]

Spence, M. (1973). Job Market Signaling. The Quarterly Journal of Economics, 87(3), 355-374.

Syahputra, F., \& Yahya, M. R. (2017). The Effect of Audit Tenure, Audit Delay, Previous Year's Audit Opinion and Opinion Shopping on the Acceptance of Going Concern Audit Opinions in Manufacturing Companies Listed on the Indonesia Stock Exchange in 2013-2015. Jurnal Ilmiah Mahasiswa Akuntansi, 2(3), 39-47. [Indonesian]

Taqi, M. (2013). Consequences of Audit Quality in Signaling Theory Perspective. GSTF Journal on Business Review, 2(4), 133-136. https://doi.org/10.5176/2010-4804_2.4.262

Teoh, S. H., \& Wong, T. J. (1993). Perceived Auditor Quality and the Earnings Response Coefficient. The Accounting Review, 68(2), 346-366.

Vu, V. T. T., Do, N. H., Dang, H. N., \& Nguyen, T. N. (2019). Profitability and the Distance to Default: Evidence from Vietnam Securities Market. Journal of Asian Finance, Economics and Business, 6(4), 53-63. https://doi.org/10.13106/ jafeb.2019.vol6.no4.53 